"This is the peer reviewed version of the following article: Samara, Muthanna, El Asam, Aiman, Khadaroo, Ameerah and Hammuda, Sara (2020) Examining the psychological wellbeing of refugee children and the role of friendship and bullying. British Journal of Educational Psychology, 90(2), pp. 301-329., which has been published in final form at https://doi.org/10.1111/bjep.12282. This article may be used for non-commercial purposes in accordance with Wiley Terms and Conditions for Use of Self-Archived Versions. 


\title{
Title:
}

\section{Examining the psychological wellbeing of refugee children and the role of friendship and bullying}

\author{
Running Title: Psycho-social Wellbeing of Refugee Children \\ Muthanna Samara*, Aiman El Asam, Ameerah Khadaroo \& Sara Hammuda
}

\section{*Professor Muthanna Samara (correspondence author)}

Department of Psychology, Kingston University London, Penrhyn Road, Kingston upon Thames KT1 2EE, United Kingdom

Email: M.Samara@Kingston.ac.uk

Tel: +44 (0) 2084172533

\section{Dr. Aiman El Asam}

Department of Psychology, Kingston University London, Penrhyn Road, Kingston upon Thames KT1 2EE, United Kingdom

Email: A.Elasam@Kingston.ac.uk

\section{Mrs. Ameerah Khadaroo}

Department of Psychology, Warwick University, Coventry, CV4 7AL, United Kingdom Email: A.khadaroo@warwick.ac.uk

\section{Mrs. Sara Hammuda}

Department of Psychology, Kingston University London, Penrhyn Road, Kingston upon Thames KT1 2EE, United Kingdom

Email: Sarahammuda@hotmail.com

\section{Acknowledgements:}

This work was supported by the Qatar National Research Fund (QNRF) a member of Qatar Foundation Doha, Qatar, National Priority Research Programs (NPRP) under Grant (NPRP 7 - 154 - 3 - 034). The authors would like to thank QNRF for their support. We would like also to thank all the schools, teachers, parents and children for their time and willingness to participate in this research study. 


\title{
Examining the psychological wellbeing of refugee children and the role of friendship and bullying
}

\begin{abstract}
Background: Refugee children might have experienced violent and traumatic events before settling into a new country. In the UK, the number of refugee children is increasing however little is known about their psycho-social and physical wellbeing.

Aim: This study aims to investigate the psychological wellbeing and behaviour of refugee children compared to British born children on a number of psychological, social, behavioural and health related issues and to investigate the role of friendship as a protective factor.

Samples: This study utilised a sample of 149 refugee children recruited from two charities, 79 of which are children aged 6 to 10 years and 70 older refugee children aged 11 to 16 years. The study also included 120 non-refugee children recruited from primary schools aged 6 to 10 years.

Methods: This is a cross-sectional study that investigates the psycho-social wellbeing of refugee children compared to non-refugee British born children. In doing so this study explored symptoms of PTSD, Emotional and Behavioural Problems (SDQ), Self-Esteem, Friendships and Popularity, Bullying and Victimisation, Physical Health and Psychosomatic Problems.

Results: Young refugee children reported more peer problems, functional impairment, physical and psychosomatic problems compared to the control children and older refugee children groups. On the other hand, older refugee children had lower self-esteem (academic and social self-peers) compared to the younger refugee children group. The differences between the groups were explained by friendship quality, number of friends, peer bullying or victimisation, or sibling bullying or victimisation except for physical and psychosomatic problems.
\end{abstract}


Conclusions: While refugee children were found to be at risk on various levels, the findings also point to the fact that social relationships including friendship quality and number of friends played an essential protective role. Conversely, bullying was a risk factor that explained many of the refugees' problems. These findings pave the way for future research to further probe into the wellbeing of refugee children in the UK while also targeting relevant intervention schemes specifically tailored to address their needs.

Keywords: Refugee children; psychological wellbeing; social wellbeing; mental health; friendship; bullying; victimisation; sibling relationships; peer relationships; health 


\section{Introduction}

People flee their homes as a result of persecution, war and political violence. The number of displaced people worldwide is currently estimated at an unprecedented 68.5 million. Nearly 25.4 million of these are considered to be refugees and more than half are children (United Nations High Commissioner for Refugees [UNHCR], 2018).

Refugee children compared to other groups of vulnerable and at-risk children are more prone to develop psychological disturbances (Bronstein \& Montgomery, 2011; Fazel, Reed, PanterBrick \& Stein, 2012). Some studies have found that at the onset of migration, refugee children exhibit conduct problems and several social and behavioural problems which may worsen during the process of migration (Hodes, 1998a, 2000, 2002b; Hodes \& Tolmac, 2005). The loss of their native land can create a deep grievance, which could affect their mental health and their functioning (Worthington, 2001; Betancourt et al., 2015), while relocation to a new unfamiliar environment can trigger a loss of self-identification, sense of security and well-being (Mann, 2010; Worthington, 2001). The experience of a myriad of stressors from both their past and new life leads refugee children to exhibit more behavioural difficulties than non-refugee children (Ehntholt \& Yule, 2006; Derluyn \& Broekaert, 2007). Psychological disturbances experienced by the children include posttraumatic stress disorder (PTSD: ranging between 1954\%) anxiety disorders, depression, psychosomatic symptoms and physical illnesses (Ugwuegbu \& Temowo, 1995; Montgomery \& Foldspang, 2005; Bronstein \& Mongomery, 2011; Bronstein, Montgomery \& Dobrowolski, 2012; Dimitry, 2012). The experience of warrelated traumatic events was also associated with intense rivalry in sibling relations and low friendship quality among young children (Peltonen, Qouta, El Sarraj, \& Punamäki, 2010).

UK-based studies found that more than a quarter of refugee children had at least one psychological disorder and were three times more likely to be affected compared to British 
children (Fazel \& Stein, 2003). Overall there was a positive correlation between pre-migration traumatic experiences and symptoms of PTSD. However, in comparison to PTSD, the social and emotional behaviour, quality of life and life satisfaction of refugee children have not been widely investigated, especially in the UK (Fazel, Reed, Panter-Brick, \& Stein, 2012).

It has long been acknowledged that while facing ongoing challenges to settle in the new country, refugee children also struggle to adapt to their new school environment. Some studies have reported that refugee children are often victims of prejudice and bullying (Fangen, 2006; Correa-Velez, Gifford, \& Barnet, 2010) and this may exacerbate certain problems including a decline in self-esteem, anxiety, depression, underachievement at school, behaviour and peer problems (Buhs \& Ladd, 2001; Juvonen, Graham, \& Schuster, 2003). The value of socialising and friendship is huge in the life of refugee children (Dunkerley, Scourfield, Maegusuku-Hewett \& Smalley, 2006) and helps to buffer the exhibition of externalising problems such as bullying (Hodges, Boivin, Vitaro \& Bukowski, 1999: Bollmer, Milich, Harris, \& Maras, 2005), conduct problems (Hartup, 1995) as well as suppress the feeling of anxiety (Fordham \& Stevenson-Hinde, 1999) and loneliness (Parker \& Asher, 1993). In addition, high quality friendship helped to promote children's self-esteem and increase their ability to cope with stressors (Hartup \& Stevens, 1999; Bolger, Patterson, \& Kupersmidt, 1998), limit behavioural and internalising problems, and foster self-worth in children and adolescents (Way \& Greene, 2005; Rubin et al., 2004).

However, while facing ongoing challenges to settle in the new country, developing friendships and integrating into a new school environment can be a struggle for refugee children (Hope, 2008). From a theoretical stand point, developing a sense of belonging at school paves the way for more attachment, commitment, involvement and faith in the educational environment (Wehlage et al., 1989). The adaptation and settling process is highly 
influenced by the amount of support these children receive at school (Hamilton, 2003; Sirin \& Rogers-Sirin, 2015). Young refugees are better able to integrate in their school environment if they are offered a space to feel safe, interact with others positively and learn (Matthews, 2008). Schools are increasingly acknowledging the important role played by friendships in promoting wellbeing amongst children (e.g., Closs et al., 2001; Hek, 2005; Candappa \& Ahmad, 2007). This endeavour is often realised with the help of school clubs that provide a platform for refugee children to engage in social interactions (e.g., Candappa \& Ahmad, 2007). These after-school clubs can also contribute towards improving academic performance with the assistance of teachers. The key role played by teachers in supporting young refugees to cope with trauma and providing them with a positive environment is important for nurturing their wellbeing both at school and outside (Szente, Hoot, \& Taylor, 2006).

However, there is a lack of empirical research concerning the experiences and well-being of refugee children in the UK (Dunkerley, Scourfield, Maegusuku-Hewett, \& Smalley, 2006; Carswell, Blackburn, \& Barker, 2011) especially in relation to the importance of social networks (Hodes et al., 2008) and various societal contexts in which refugee children live and build their experiences (Fazel et al., 2012; Bronstein \& Mongomery, 2011; Tyrer, \& Fazel, 2014). Such research is needed for the development of effective interventions aimed at promoting positive growth across different levels namely physical, social, emotional and psychological.

Furthermore, to date there is still very limited research investigating the type of care that schools can provide to these refugee children (Due \& Riggs, 2016). This is despite knowledge that they are highly at risk of experiencing learning difficulties, behavioural issues, below average academic outcomes in addition to psychological distress (Hamilton \& 
Moore, 2004). Also, the specific role played by after-school clubs for the betterment of refugee children is not widely researched, although there is evidence suggesting that these support services have the potential to help minority children in a number of ways; both on a social and emotional level (Halpern, 2000). Importantly, and from a wellbeing perspective, these psycho-social measures are also very relevant in the context of refugee children and their education. Psycho-social wellbeing measures include psychological symptoms that could affect the life of refugees, while also taking into account their social involvement with siblings at home and peers at school (number of friends, quality of friendship, and bullying/victimisation involvement).

Hence, the current study aims to investigate whether refugee children taking part in after school clubs differ from their British-born peers in relation to various psychological (e.g., PTSD, self-esteem, life satisfaction), health, psychosomatic, behavioural and social factors. The aim is also to investigate the role of the number of friends, quality of friendship or bullying/victimisation by peers and siblings in explaining these difficulties.

\section{Methods}

\section{Participants}

There were 269 participants. A total of 149 were refugee children/adolescents aged 6 to 16 years. Of the refugee group 79 were children aged 6 to 10 years (57\% females and $43 \%$ males) and 70 older refugee children/adolescents aged 11 to 16 years (59\% females and $41 \%$ males). The refugee sample represented refugee children/adolescents born outside the UK, all of whom have fled from conflict/war-torn countries (Afghani origin, 114, 76\%, or of an African country origin, $\mathrm{N}: 36,24 \%)$. Most of the refugees were living with both parents (younger refugee children: $77.3 \%$; older refugee children: $81.4 \%$ ), one of the parents 
(younger refugee children: $21.3 \%$; older refugee children: 17.1\%) or with relatives (younger refugee children: $1.4 \%$; older refugee children: $1.5 \%$ ).

The control group comprised of 120 British-born children aged 6 to 10 years (44\% females and $56 \%$ males). Refugee participants were recruited via two charities in London while the control group was recruited from seven primary schools in London.

\section{Design and Procedure}

This is a cross-sectional study. Informed consent from was obtained from parents or guardians of participating children, as well as verbal and written assent from the children/adolescents. Participants were asked to fill questionnaires which aimed to investigate their well-being on various psychological levels. Participants below the age of 11 years (in the control or the refugee groups) filled in a self-report questionnaire (through a 45 mins interview with the researcher) while their parents were also asked to fill in the questionnaires (demographic details and their children's psychosomatic and physical health problems, strengths and difficulties, and PTSD). Participants aged 11 years and above (refugees only) were asked to fill in a self-report questionnaire (20-30 minutes). Questionnaires were given in English to both the control and the refugee group. All refugee children were judged to speak fluent English (by their mentors or teachers), attended mainstream schools and the researcher was present for clarifications and explanations when needed. Whilst the control group was surveyed or interviewed during school hours, the refugee group was surveyed during afterschool clubs run by the refugee charities. Parents who were less fluent in English were provided with questionnaires translated in their own language (mostly French, Somali and Pashto). The translation was performed by two professional translators separately for each language and they were translated and back translated to English for reasons of comparison. The SDQ has previously been translated, piloted and validated in a number of languages 
including the ones spoken by the refugee sample in this study. The study was ethically approved by the Ethics Committee at the University.

\section{Measures}

Demographic information: Demographic information about the child's gender, age, grade, school, and number of siblings were collected from both parents and children.

Satisfaction with Life Scale (SWLS) - child version (Diener, Emmons, Larson, \& Griffin, 1985) consists of five items (e.g., in most ways my life is close to my ideal) and investigates the participant's general judgement of life satisfaction. The items were scored on a 7-point Likert Scale, ranging from strongly disagree (1) to strongly agree (7) and the total scale score varies between 5 and 35 (Gadermann et al., 2010) where high score in this scale means high satisfaction with life (Cronbach's alpha was found to be 0.88).

Coopersmith Self-Esteem Inventory-Long Form (SEI): based on Coopersmith, (1981) this scale consists of 58 items, where children are asked to describe their self-esteem under five categories: general self (e.g., I am pretty sure of myself), 'social self peers' (e.g., I am easy to like), 'home parents' (e.g., I get upset easily at home), 'school academic' (e.g., I am proud of my school work) and 'lie scale' (e.g., I never worry about anything). After reversing negative items, high score in this scale or its subscales implies that the child scored high in selfesteem. All subscales were deemed reliable $(\alpha=0.73-0.85)$.

Child PTSD Symptom Scale (CPSS): This measure is the child version adapted from the original Posttraumatic Diagnostic Scale for Adults (Foa et al., 2001). The parents of children below 11 years old and the children aged 11 and above were asked to fill this 24 -item questionnaire on symptoms of PTSD experienced over the previous two weeks. Part one 
included 17 items that correspond with the DSM-IV symptoms: Re-experiencing (5 items) (e.g., having bad dreams or nightmares), avoidance (7 items) (e.g., trying to avoid activities, people, or places that remind you of the traumatic event) and hypervigilance (5 items) (e.g., having trouble falling or staying asleep). Part two included 7 items asking about functional impairment, i.e., participants were asked whether any of the previous problems indicated in part one, have affected or interfered with other aspects of their life (e.g., forming relationships). Answers to these items were based on the impairment being present (yes=1) or absent $(\mathrm{no}=0)$. For the first part, the total score of each category was calculated based on which children were described to either have PTSD symptoms (1) or not (0) based on the $90^{\text {th }}$ percentile cut-off point generated from this sample. The cut-off point is based on the frequency of the PTSD total score of the current tested sample (control and refugee). Higher scores reflect more severe symptoms. For functional impairment children who showed no experience of any problem were given the score of 0 and those who scored one problem or above had a score of 1 . Scores range from 0-7, with higher scores suggesting higher functional impairment. Using Cronbach's alpha, all subscales were reliable ( $\alpha=0.72-0.90)$.

Cambridge Hormones and Moods Friendship questionnaire: Based on research by Goodyer, Wright, and Altham $(1989,1990)$ this measure included 5 questions asking whether children are happy with: the number of friends they have; seeing friends; friends understanding; talking to friends about problems and happiness with friends. Items were assessed on 5-point Likert scale (1= very happy to 5=unhappy or hardly ever). Items scores were summed where a score of 5 reflects a very positive friendship quality whilst 25 reflects a very poor friendship quality $(\alpha=0.77)$.

Popularity Questionnaire: Children's popularity amongst peers was assessed by asking children to list up to 5 children they play with (peer acceptance) and 5 children who are not considered playmates or they do not play with (peer rejection). They were also asked to tick a 
box next to playmates who are considered best friends. This is children's own rating of their number of friends and best friends (Coie \& Dodge, 1983; Schafer, Korn, Brodbeck, Wolke, \& Schulz, 2005; Wolke, Woods, \& Samara, 2009).

Bullying and Victimisation: The first section of this questionnaire included questions about victimisation by peers at school (e.g., I was hit, kicked, pushed or threatened) and bullying other peers (e.g., I called him/her bad or nasty names). The second section was the same except that it referred to events occurring at home with siblings (victimisation or bullying). Questions in both sections included four items for direct bullying (physical and verbal) (e.g., hit, kicked, pushed or threatened), four items for relational bullying (e.g., spreading rumours and excluding from the group) and two items for cyberbullying (e.g., emails and mobile phones). The items referred to behaviours that happened in the last six months and children were asked about the frequency of these behaviour (Never: (0) never; rarely: (1) only once or twice; frequently: (2) 2-3 times a month, (3) about once a week, (4) several times a week). Then the answers never and rarely were considered as not involved in regular bullying, whereas frequently was considered as the child being regularly involved in bullying. Based on the overall scores, children were described as pure bullies (pupils who were involved in bullying others frequently but are never or rarely victimised), pure victims frequently victimised but bully others never or rarely), bully/victims (pupils who both bully others and become victims frequently) or neutral (who neither bully others nor become victims (never or rarely only)) for each bullying type (direct, relational and cyber) (Wolke et al., 2000; Wolke \& Samara, 2004). Bullying and victimisation subscales were reliable $(\alpha=0.71-0.78)$.

Strengths and Difficulties Questionnaire (SDQ): Parents of children below 11 years old and children aged 11 and above completed the SDQ questionnaire, which aims to gain insight 
into behavioural and emotional problems amongst children aged 4 to 17 years (Goodman et al., 2005). The SDQ (English version) has 25 items with each 5 items added together to construct a specific subscale. The subscales are conduct, emotional, hyperactivity and peer problems, and prosocial behaviour. The total 20 items (except the prosocial) represent total difficulties scale. All scales achieved high reliability $(\alpha=0.73-0.84)$. When looking at the reliability of the self and parental SDQ reports separately, hyperactivity, peer and conduct parental subscales had higher reliability compared to the self-report subscales, while the reliability was a bit higher for self-report total difficulties and emotional subscales. Scoring high SDQ subscales (apart from prosocial behaviour) indicate difficulties. The subscales and the total scale were further categorised into normal (below the $80^{\text {th }}$ percentile), borderline (between the $80^{\text {th }}-89^{\text {th }}$ percentile) and clinical $\left(90^{\text {th }}\right.$ percentile and above) ranges according to the percentiles generated from the current sample.

Psychosomatic and Health Questionnaire: Parents of children below 11 years old and children aged 11 and above completed the psychosomatic and health questionnaire. The first section of the questionnaire consists of 7 items tapping into the child's physical health problems (PHP) over the past twelve months (scored on 0 to 6 or more times) (e.g., number of times the child complained of headache). The second section has seven items which enquire about psychosomatic health problems (PsHP), over the past twelve months. Items were scored on a 5-point scale (never to most days) (e.g., number of times the child had problems going to sleep) (Wolke, Woods, Bloomfield, \& Karstadt, 2001). For both sections, higher scores reflect more severe difficulties pertaining to physical health and psychosomatic health. Both psychosomatic and physical heath scales were reliable $(\alpha=0.78$ and $\alpha=0.81$ respectively). The total scales were further categorised into normal (below the $80^{\text {th }}$ 
percentile), borderline (between the $80^{\text {th }}-89^{\text {th }}$ percentile) and clinical $\left(90^{\text {th }}\right.$ percentile and above) ranges according to the percentiles generated from the current sample.

Finally, as all questionnaires used were judged to be reliable, a further attempt was made to see whether the reliability differed between the different groups (refugees and control) and amongst different ethnicities within the refugee group (Afghani vs. African countries). Although the reliability fluctuated across groups, no groups generated a reliability score below 0.70 in any of the scales or subscales used.

\section{Statistical analysis:}

Younger refugee children, older refugee children and the young control group were compared with each other in the current analysis. To determine the differences between these groups in relation to demographic, psychological and behavioural factors, one-way ANOVAs were computed and a posteriori contrasts computed with the Bonferroni test (SPSS version 24). Effect size (ES) for mean difference was computed as Eta square according to Tabachnick and Fidell (p. 545-545, SPSS version 24) (1989). Categorical analysis using Chi Square was performed to determine differences in relative frequencies of children in different groups in relation to bullying status groups according to type (direct, relational) at home with siblings and at school with peers. It was also used to test differences between groups in relation to the categorisation of normal $\left(<80^{\text {th }}\right.$ percentile) versus borderline/clinical $\left(\geq 80^{\text {th }}\right.$ percentile) psychological and behavioural problems of children and $\geq 90^{\text {th }}$ percentile for PTSD. Variables were categorised according to the percentiles generated from the current sample. Linear regression (Enter method) and logistic regression (Enter method) were used to determine the unique effects of group (younger refugee children vs. control; younger refugee children vs. older refugee children; older refugee children vs. control) on psychological and 
behavioural problems. The dependent variable (DV) for the linear regression was the psychological and behavioural scales and for the logistic regression the categorisation normal versus borderline/clinical psychological and behavioural problems of children. The regression analyses were run again for each outcome while adjusting for each of the following factors individually to see whether they explain differences between the groups: number of friends, friendship quality, overall peer bullying, overall peer victimization, overall sibling bullying and overall sibling victimization.

\section{Results}

\section{Group Differences:}

An independent samples One Way Analysis of Variance was conducted to examine differences between the control group (6-10 years of age), younger refugee children sample (6-10 years of age) and older refugee children sample (11-16 years of age). ANOVA was tested on different psychological, behavioural and health factors amongst the three groups (Table 1).

Sibling and Friendship: ANOVA revealed significant differences between the three groups in the number of siblings $\left(F(2,258)=23.81, \mathrm{p}<0.001, \eta^{2}=0.211\right)$ (control group: 1.54 ; younger refugee children: 2.58; older refugee children: 3.97). Bonferroni post-hoc test showed significant differences between any two of the three groups (control vs. younger refugee children: $\mathrm{p}<0.05$; control vs. older refugee children: $\mathrm{p}<0.001$; older refugee children vs. younger refugee children: $\mathrm{p}=0.01$ ). While chi-square analysis revealed that the control group were more likely to be the youngest (N:39/73; 53.4\%), and the eldest (N: 24/73; 32.9\%,) 
sibling in the family compared to the younger refugee children group (youngest sibling: $\mathrm{N}$ : 20/75; 26.7\%; eldest sibling: $\mathrm{N}: 17 / 75 ; 22.7 \%$ ) and the older refugee children group (youngest sibling: N: 27/69; 39.1\%; eldest sibling: N: 14/69; 20.3\%). On the other hand, younger refugee children group were more likely to be the middle sibling (N: $38 / 75 ; 50.7 \%$ ) compared to the control group $(\mathrm{N}: 10 / 73 ; 13.7 \%)$ and older refugee children group (N: 28/69; $40.6 \%)\left\{\chi^{2}(4,217)=24.55, p<0.001\right\}$. Furthermore, post hoc analysis revealed that the control group had significantly less number of friends compared to the two refugee groups $\left(\mathrm{F}(2,213)=38.17, \mathrm{p}<0.001, \mathrm{\eta}^{2}=0.438\right)$ (control group: 3.45 ; younger refugee children group: 4.62; older refugee children group: 4.89) $(\mathrm{p}<0.001)$. Overall distribution analysis confirmed that children indicated that they have different number of friends with the majority to indicate that they have 5 friends (65.9\%). Within group analysis confirmed the above results where refugee children indicated that they mostly have 5 friends (younger refugee children: $69.6 \%$; older refugee children: $72.9 \%$ ) in comparison to the control group (30\%). No significant differences were found with regards to the number of best friends and children's friendship quality $(\mathrm{p}>0.05)$.

Psychological wellbeing: Significant differences were also observed in the school-academic self-esteem $\left(F(2,213)=5.10, \mathrm{p}<0.01, \eta^{2}=0.110\right)$; post-hoc test showed significant difference between the older refugee children group (Mean: 3.51) compared to the younger refugee children group (Mean: 4.13) $(\mathrm{p}<0.05)$ and the control group (Mean: 4.30) $(\mathrm{p}<0.01)$. Furthermore, significant difference was found in general self-esteem subscale $(F(2,215)=$ $\mathrm{p}=0.011, \eta^{2}=0.020$ ); post-hoc test showed significant difference between the control group (Mean: 15.80) and the older refugee children group only (Mean: 18.44) $(\mathrm{p}<0.05)$. Difference was also observed in social self-peers subscale $\left(F(2,212)=4.475 p=0.012, \eta^{2}=0.124\right)$ (Y.C=3.96, YR=4.35, O.R=3.61), where post-hoc statistics showed significant difference 
between older refugee children group (Mean: 3.61) and younger refugee children group (Mean: 4.35) $(\mathrm{p}<0.01)$. No differences were found in other self-esteem subscales and the total self-esteem scale $(\mathrm{p}>0.05)$.

There were also significant differences in the peer problems subscale $(F(2,195)=9.57$, $\mathrm{p}<0.001, \eta^{2}=0.206$ ), where younger refugee children scored higher mean scores for peer problems (Mean: 3.65) compared to the older refugee children (Mean: 2.26) $(\mathrm{p}<0.01)$ and the control groups (Mean: 2.10) $(\mathrm{p}<0.001)$. No significant differences were found for the other SDQ subscales and total difficulties ( $p>0.05)$.

The results revealed that although the control group showed slightly better level of satisfaction with life compared to the refugee group the difference was not significant. Finally the three groups significantly differed in functional impairment $(F(2,95)=15.12$, $\mathrm{p}<0.001, \eta^{2}=0.251$ ), where younger refugee children showed significantly higher mean score (Mean: 4.47) compared to the control (Mean: 1.38) $(\mathrm{p}<0.001)$ and the older refugee children (Mean: 2.44) groups ( $\mathrm{p}=0.001)$. No significant differences were found across the other PTSD symptoms and PTSD total $(p>0.05)$.

Health status: Significant differences were found in total physical health problems $\left(F(2,219)=7.83, p<0.01, \eta^{2}=0.037\right)$, where younger refugee children (Mean: 11.94) and older refugee children (Mean: 12.58) had significantly higher number of physical illnesses compared to the control group (Mean: 7.95) $(\mathrm{p}<0.01)$. No difference was found in psychosomatic health scale $(\mathrm{p}>0.05)$.

Gender differences: The role of gender was examined within each of the three groups, using Independent Samples t-test, it was evident that gender had no impact on all variables within the control group, younger refugee children group and older refugee children group ( $p>0.05)$. 


\section{INSERT TABLE 1 HERE}

Psychological problems in the clinical range: When categorising participants into normal (below the $80^{\text {th }}$ percentile) versus borderline/clinical (equal and above the $80^{\text {th }}$ percentile) in all psychological and health factors, younger refugee children were more likely to fall into the borderline/clinical range for peer problems $(\mathrm{N}: 34 / 51 ; 66.7 \%)$ compared to the control group $(\mathrm{N}: 33 / 93 ; 35.5 \%)\left\{\chi^{2}=12.87, \mathrm{p}<0.01 ; \mathrm{OR}=3.63\right.$, CI: $\left.\left.1.76-7.47\right)\right\}$, and compared to the older refugee children group $(\mathrm{N}: 17 / 54 ; 31.5 \%)\left\{\chi^{2}=12.99, \mathrm{p}<0.001 ; \mathrm{OR}=0.23,95 \%\right.$ $\mathrm{CI}=0.101-0.520)\}$. Furthermore, younger refugee children were more likely to fall into the borderline/clinical range of psychosomatic problems (N: 14/79; 17.7\%) compared to the control group $(\mathrm{N}: 5 / 120 ; 4.2 \%)\left\{\chi^{2}=10.13, \mathrm{p}<0.01 ; \mathrm{OR}=4.95,95 \% \mathrm{CI}=1.70-14.33\right\}$. With regards to total health problems, the results showed that the older refugee children group is more likely to fall into the borderline/clinical range (N: 11/70; 15.7\%) compared to the control group $(\mathrm{N}: 6 / 120 ; 5 \%)\left\{\chi^{2}=6.23, \mathrm{p}<0.05, \mathrm{OR}=3.54\right.$, CI: $\left.1.24-10.05\right\}$.

In terms of functional impairment, younger refugee children were more likely to fall into the clinical range (above the $90^{\text {th }}$ percentile) $(\mathrm{N}: 14 / 30 ; 46.7 \%)$ compared to the control group $(\mathrm{N}: 2 / 32 ; 6.3 \%)\left\{\chi^{2}=13.21, \mathrm{p}<0.001, \mathrm{OR}=13.12,95 \% \mathrm{CI}=2.64-65.07\right\}$ and compared to the older refugee children group $(\mathrm{N}: 6 / 36 ; 16.7 \%)\left\{\chi^{2}=6.97, \mathrm{p}<0.01, \mathrm{OR}=0.23,95 \% \mathrm{CI}=\right.$ $0.074-0.71\}$

Bullying and Victimisation Behaviour: The prevalence of bullying and victimisation between peers and siblings across the three groups is shown in table 2. Comparisons between each of the two groups were performed. 
When comparing the control group with the younger refugee children group, the control group was significantly more likely to be direct sibling victims $\left(\chi^{2}=9.84, p<0.05\right)$ and relational sibling victims $\left(\chi^{2}=8.93, p<0.05\right)$ compared to the younger refugee children group. They were also more likely to be relational sibling bully/victims. However, younger refugee children were more likely to be relational sibling bullies compared to the control group. No significant differences were found with regards to peer bullying between the two groups. By comparing the younger refugee children group with the older refugee children group, significant differences were observed in peer direct bullying $\left(\chi^{2}=20.03, p<0.001\right)$, peer relational bullying $\left(\chi^{2}=26.85, \mathrm{p}<0.001\right)$, overall peer bullying $\left(\chi^{2}=25.00, \mathrm{p}<0.001\right)$ and overall sibling bullying $\left(\chi^{2}=12.59, \mathrm{p}<0.001\right)$. Younger refugee children were more likely to fall in the victim and bully/victim categories in all types of bullying.

Furthermore, the older refugee children group was compared with the control group. Significant difference was found in peer direct $\left(\chi^{2}=11.48, \mathrm{p}<0.01\right)$, peer relational $\left(\chi^{2}=20.87\right.$, $\mathrm{p}<0.001)$, overall peer $\left(\chi^{2}=20.17, \mathrm{p}<0.001\right)$, sibling direct $\left(\chi^{2}=31.32, \mathrm{p}<0.001\right)$, sibling relational $\left(\chi^{2}=17.33, \mathrm{p}<0.001\right)$ and overall sibling $\left(\chi^{2}=31.28, \mathrm{p}<0.001\right)$ bullying. The control group was more likely to be victims and bully/victims across all bullying types compared to the older refugee children group.

\section{INSERT TABLE 2 HERE}

\section{The role of friendship and bullying:}

Based on the significant results from the previous analysis, a series of separate linear regression analyses were conducted to test whether group status (control vs. younger refugee children; control vs. older refugee children; younger refugee children vs. older refugee children) predicts psychological and behavioural problems before and after adjusting for friendship quality, number of friends, peer bullying/victimisation or sibling 
bullying/victimisation. Seven regression analyses were performed including the following predictors separately: (1) group only; (2) group and friendship; (3) group and number of friends; (4) group and peer victim; (5) group and peer bully; (6) group and sibling victim; (7) group and sibling bully. The outcomes included: School academic self-esteem, general selfesteem, physical health, peer problems and functional impairment (Table 3). We will first present the results for group only (before adjusting for any independent predictor) and then present the results after adding each predictor separately to the model (group plus predictor). Finally, we will also indicate which predictor was significant in relation to each outcome.

It was found that the younger refugee children group, compared to the control group, predicts physical health problems, peer problems and functional impairment.

When adjusting for friendship quality the difference between both status groups disappeared for peer problems only, while adjusting for number of friends, overall peer bullying/victimisation or sibling bullying/victimisation did not change the results. From the adjusted variables, peer victimisation predicted physical health problems $(B=0.371$; $\mathrm{p}<0.001)$ and peer problems $(\mathrm{B}=0.071 ; \mathrm{p}<0.05)$, while sibling victimisation predicted physical health problems only $(B=0.261 ; \mathrm{p}<0.01)$. The other independent predictors were not significant.

On the other hand, the younger refugee children group, in comparison to the older refugee children group, predicts higher school/academic self-esteem, peer problems and functional impairment, whereas the older refugee children group predicts higher general selfesteem. However, the differences for school-academic self-esteem and for general selfesteem disappeared when adjusting for number of friends, overall peer victimisation or overall sibling victimisation. On the other hand, the differences for peer problems disappeared when adjusting for peer victimisation. 
From the adjusted variables, negative friendship quality predicted high peer problems $(B=-$ $0.176, \mathrm{p}<0.05)$. Furthermore, peer victimisation predicted higher school/academic self-esteem $(B=0.042, p<0.05)$, lower general self-esteem $(B=-0.168, p<0.05)$ and peer problems ( $B=0.084, p<0.05)$, while sibling victimisation predicted higher school academic self-esteem $(B=0.059, \mathrm{p}<0.01)$. The other independent predictors were not significant.

It was found that the young control group compared to older refugee children group predicts high school/academic self-esteem, whereas the older refugee children group predicts high general self-esteem, physical health problems and functional impairment.

When adjusting for number of friends, the differences disappeared for general selfesteem and for functional impairment. On the other hand, when adjusting for friendship quality the differences disappeared for functional impairment only. When adjusting for overall peer victimisation the differences for school-academic self-esteem has disappeared, while adjusting for any of the bullying/victimisation by peers or siblings explained the differences for functional impairments (see Table 3).

From the adjusted variables, positive friendship quality predicted high general self-esteem $(B=0.386, p<0.01)$; sibling victimisation predicted high school academic self-esteem $(\mathrm{B}=0.044, \mathrm{p}<0.05)$ and physical problems $(\mathrm{B}=0.216, \mathrm{p}<0.05)$; whilst peer victimisation predicted low general self-esteem $(B=-0.163, p<0.05)$ and physical problems $(B=0.291$, $\mathrm{p}<0.01)$. The other independent predictors were not significant.

\section{INSERT TABLE 3 HERE}

Using logistic regression, younger refugee children, compared to the control group, were more likely to fall in the borderline/clinical category for peer problems $(B=1.291$, $\mathrm{p}<0.001, \mathrm{OR}=3.64 ; 95 \%$ CI: 1.77-7.48), total psychosomatic problems $(\mathrm{B}=1.600, \mathrm{p}<0.01$, $\mathrm{OR}=4.95 ; 95 \% \mathrm{CI}: 1.71-14.38)$, and functional impairment $(\mathrm{B}=2.575, \mathrm{p}<0.01 ; \mathrm{OR}=13.12$; 
95\% CI: 2.65-65.08). When adjusting for friendship quality the differences disappeared for peer problems ( $B=0.584, p>0.05$; OR: $1.79 ; 95 \% \mathrm{CI}$ : 0.78-4.12). On the hand, the differences disappeared in functional impairment when adjusting for number of friends $(B=7.183$, $\mathrm{p}>0.05)$.

When looking at the adjusted variables it was revealed that total psychosomatic problems were predicted by negative friendship quality $(B=-0.148$, p<0.05; OR: $0.863 ; 95 \%$ CI: $0.753-$ 0.988), peer victimisation $(B=0.118, \mathrm{p}<0.01$; OR: 1.126 ; $95 \%$ CI: $1.050-1.207)$ and sibling bullying ( $\mathrm{B}=0.089, \mathrm{p}<0.05$; OR: 1.093; 95\% CI: 1.015-1.178). On the other hand, peer problems were predicted by peer victimisation $(B=0.074$, $p<0.05$; OR: 1.077 ; $95 \%$ CI: $1.015-$ 1.143) and peer bullying ( $\mathrm{B}=0.131, \mathrm{p}<0.01$; OR: 1.140; 95\% CI: 1.034-1.257). The other independent predictors were not significant.

Furthermore, younger refugee children compared to older refugee children were significantly more likely to be in the borderline-clinical range for functional impairments $(\mathrm{B}=$ -1.476; $\mathrm{p}<0.011$; OR: 0.229; 95\% CI: 0.074-0.709) and peer problems $(\mathrm{B}=-1.471 ; \mathrm{p}<0.001$; OR: 0.230 ; 95\% CI: 0.101-0.520). None of the adjusted variables explained these differences.

From the adjusted variables, peer problems were predicted by peer victims $(B=0.108$, p<0.05; OR: 1.114; 95\% CI: 1.014-1.224), while the other independent predictors were not significant.

Older refugee children compared to the control group were significantly more likely to have physical problems in the borderline-clinical range $(B=0.632 ; \mathrm{p}<0.05 ; \mathrm{OR}: 1.88 ; 95 \%$ CI: 1.11-3.17), which was explained by number of friends $(B=0.602 ; p<0.05 ;$ OR: $1.83 ; 95 \%$ CI: 0.90-3.70). None of the other adjusted variables explained these differences (friendship quality, bullying/victimisation by peers and siblings). 
From the adjusted factors, peer victims significantly predicted physical problems $(\mathrm{B}=$ 0.102 , p < 0.05 ; OR: $1.107 ; 95 \%$ CI: 1.010-1.14). The other independent predictors were not significant. 


\section{Discussion}

This research was conducted with an aim to assess the psychological and behavioural wellbeing of refugee children in the UK compared to British-born children and the effect of friendship, bullying and number of friends on this. Furthermore, we were able to look at age differences within the refugee group.

Psychological wellbeing: Satisfaction with life was not found to be significantly different between the refugee and the control group. It can be speculated that refugees in general might view their life as ideal or close to ideal given that they left their troubled background (e.g., poor or conflict - torn countries) for a peaceful place. However, we cannot know what specific situations these refugees have experienced and what daily stressors they are currently facing in the UK. Thus, future research should use tools that address specific difficulties that refugee children and adolescents face before and during their journey, and when settled (Gullone \& Cummins, 1999). Such new tools are being developed to help address this gap in knowledge, measuring factors such as resilience (Yale University, 2017) and well-being (Scales et al., 2015) amongst refugee children.

In terms of self-esteem, compared to the younger refugee children and the control group, older refugee children had significantly lower self-esteem in the school-academic subscale. This could be due to language problems or "being different." Language problems (even among those considered to be 'fluent') can lead to poor school achievement, whilst being different could lead to isolation and thus to low self-esteem in the school environment (e.g., Buhs \& Ladd, 2001; Furlong, Sharma, \& Rhee, 2000; Juvonen, Graham, \& Schuster, 2003; Watkins, Razee, \& Richters, 2012). On the other hand, the older refugee children group were also more likely to have lower social self-peer self-esteem compared to the younger refugee children group. This appears to indicate that the older the refugee children become, the more problems they acquire in relation to their self-esteem. A recent meta-analysis that investigated 
the normative trajectory of self-esteem across the life span including longitudinal data (mean age ranged from 4 to 94 years), revealed that average levels of self-esteem increased from age 4 to 11 years, remained stable from age 11 to 15 , and increased strongly until age 30 years (Orth, Erol, \& Luciano, 2018). Thus, during adolescence, self-esteem is more stable compared to childhood. In this study the older refugee children had lower self-esteem compared to the younger groups. This may be due to psychosocial crises occurring as part of normal adolescent development or may be due to these normal crises being exacerbated due to the children's difficult past experiences as refugees (Lustig et al., 2004).

With regards to behavioural and emotional problems, it was found that younger refugee children were significantly more likely to have peer problems in comparison to the control and older refugee children groups and were more likely to be in the clinical range for peer problems. However, group differences in peer problems disappear when controlling for friendship quality.

No differences were observed regarding the other subscales and the total scale of the SDQ. In general, similar to the current findings, there is evidence pointing to the fact that following the experience of a myriad of stressors from both their past and new life, refugee children are more prone to exhibit behavioural difficulties than non-refugee children (Ehntholt \& Yule, 2006; Lustig, Kia-Keating, Grant-Knight et al., 2004; Hodes, 1998a, 2000, 2002b; Hodes \& Tolmac, 2005; Howard \& Hodes, 2000; Shallow \& Whitington, 2014). Peer problems could be explained by the differences between the refugee and natives (e.g. ethnicity, educational level and language) whereby such differences could lead to discrimination, and poor peer relations. There is evidence pointing towards the benefit of adopting a "pro-refugee stance" in the school context. In cases where there are existing opportunities to discuss refugee issues in a positive light as part of Personal and Social Education, students in general were all more welcoming of the new refugee students (Jones, 1998, p.178). 
The results on PTSD from this study contradict earlier findings that refugee children are at risk of suffering from PTSD (e.g., Almqvist \& Brandell-Forsberg, 1997; Rothe et al., 2002; Servan-Schreiber, Le Lin, \& Birmaher, 1998). According to Derluyn and Broekaert (2007). There is evidence suggesting that in the absence of support and protection from a parent/primary caregiver the emotional well-being of a refugee child is prone to suffer from a negative impact with a high prevalence of internalising issues such as anxiety, depression, emotional problems and post-traumatic stress symptoms. These problems are much more pronounced for unaccompanied than accompanied refugee adolescents (Derluyn, 2005). The vast majority of the refugee children are living with one or both parents. Furthermore, we can speculate that these children have integrated well in the UK and the interventions that these charities offer could help them to cope and bounce back and protect them from developing PTSD symptoms.

On the other hand, it was evident that the younger refugee children group had a significantly higher score of functional impairment compared to the older refugee children and control groups and were more likely to be in the clinical range for functional impairment. Although from an empirical perspective it is well documented that it is not to be assumed that most traumatized youth would develop PTSD (as in the current study), there is also accumulating evidence confirming a positive correlation between the experience of several traumatic events and PTSD (e.g., Breslau, Wilcox, Storr, Lucia, \& Anthony, 2004; Thabet, Abed, \& Vostanis, 2004). As there were no significant differences with regards to PTSD in this study, we reported the effect size for functional impairment which was large. It could be that functional impairment is influenced also by more general measure of impairment (e.g., physical health and psychosomatic problems) in addition to the effects of previous traumatic experiences. Younger refugee children scored higher on functional impairment and peer problems than the older refugee children. It has been previously highlighted that the hardships faced by younger 
refugee children can contribute towards delayed cognitive development, lead to difficulties in attention regulation as well as hinder the development of normal attachment patterns and relationships (Roy, Rutter, \& Pickles, 2004).

Furthermore, younger and older refugee children groups were found to have higher number of physical illnesses compared to the control group. Similarly, previous studies investigating Middle Eastern refugee children in Denmark (Montgomery \& Foldspang, 2005) and Liberian refugees in Nigeria (Ugwuegbu \& Temowo, 1995) found that refugees were more likely to have psychosomatic and psychological disturbances as well as various forms of physical and mental illnesses compared to non-refugees. In particular, younger refugee children scored higher on the clinical range for psychosomatic problems than the control group while the older refugee children scored higher on the clinical range for physical problems compared to the control group. It is clear that child refugee age is important to consider bearing in mind that the younger the child, the less likely it would be for them to effectively cope with their experience as a refugee and thus they could develop psychosomatic problems, which in turn can be expressed as physical problems over time.

Physical health problem was not explained by friendship quality. We can only speculate that this could be explained by a possible lack of access to healthcare during earlier life and during displacement.

The role of friendship and bullying: When considering the number of friends, the refugee groups had significantly higher number of friends compared to the control group, however, no differences were found with regards to the number of best friends and friendship quality. In our study, we found that peer problems were mediated and explained by friendship quality such that this difference between the two groups was no longer observed. Thus, friendship quality has an immense advantage for refugee children (Cole \& Brown, 2002; Dunkerley et 
al., 2006; Derluyn et al., 2008) especially as a protective factor with regards to the emotional development of young people (Savin-Williams \& Berndt, 1990; Hartup, 1993).

On the other hand, number of friends has explained the difference between both refugee groups with regards to school academic self-esteem and general self-esteem. According to Peltonen et al. (2012) friendship could have the potential to buffer the impact of adverse trauma outcomes on children's mental health. It seems that the number of friends that the person has can also improve their school academic self-esteem. It can also be speculated that children who do well academically are also more likely to be the ones who are more popular, hence with more friends, than those who are struggling with their studies. Past research has also noted a strong positive impact of friendship on children's and adolescents' self-esteem and self-worth (Hartup \& Stevens, 1999; Hansen, Giacoletti, \& Nangie, 1995; Savin-Williams \& Bemdt, 1990). In addition, peer or sibling victimisation explained the differences with regards to self-esteem and peer problems between the younger and the older refugee children groups.

All the refugee children in this study attend afterschool activities including social events and sports. During these activities refugee children can form friendship links and ties. Similarly, Hek and Sales (2002) and Stanley (2001) have reported positive friendship ties often built during activities, discussions and lunch breaks between refugee children and peers from their own, as well as different cultural backgrounds. This can also explain the findings with regards to peer bullying that indicated no significant differences between the younger refugee children group and the control group across all peer bullying forms. However, refugees have been found to have higher peer problems compared to the control group, which were explained by friendship quality, with negative friendship quality predicting high peer problems. Peer problems in this context represent loneliness, whether the child is liked by others and whether he/she is better with adults than with children. It also includes a question 
about being bullied and picked on. Thus, it seems that there is a trend towards peer problems in general rather than a specific form of bullying.

Previous research revealed no differences in bullying and victimisation among refugee children and natives (Fandrem et al., 2009; McKenney, Pepler, Craig, \& Connolly, 2006; Monks, Ortega-Ruiz, \& Rodriguez-Hidalgo, 2008). Dodds et al. (2010) undertook a study on the children of Somali refugees in Australia and similar to this study, peer bullying was not an issue amongst these children. Since the refugees in the current study actively participated in afterschool activities revealing a willingness to integrate in their new educational setting, this could have significantly limited the likelihood of being peer bullied or at least prevented the likelihood of it from being significantly different from British children.

On the other hand, results for sibling bullying indicated a significant difference between both groups in direct, relational and overall bullying. The control group were more likely to be involved in sibling direct and relational as pure victims and relational bully/victims compared to the younger refugee children group. In contrast, younger refugee children were more likely to be relational pure bullies. Refugee children (younger and older) were found to have more siblings and to be more often the middle sibling in the family, especially the younger refugee children group, compared to the control group. This is confounded with large family size for refugee children and small family size (1-2 children) for control children.

This difference in sibling number of the control versus refugee families may explain the differences seen in the types and prevalence of sibling bullying. Furthermore, in the younger refugee children families there often tends to be an older sibling looking after the younger ones. Thus, there is always a risk for potential tensions arising as a result of a lack of clarity in terms of who is in charge and the rules to be followed (Richman, 1998a). Caring for 
siblings often puts a lot of pressure on family relationships (Stanley, 2001), which can be one of the leading causes of relational sibling bullying.

There could be also cultural differences in understanding some of the questions related to bullying and victimisation and this may explain some of the results found in relation to peer and sibling bullying (Scheithauer, Smith, \& Samara, 2016).

With reference to age, younger refugee children scored higher on peer problems as well as being more likely to become victims and bully/victims (with peers and siblings) than older refugee children. In line with Hamilton (2003) and Sirin and Rogers-Sirin (2015), it is plausible to witness more difficulties amongst younger than older refugee children in terms of adapting to their new school environment. As children grow older, they are more likely to develop better interpersonal skills than their younger counterparts. The differences between the older refugee children group and the control group for functional impairments were also explained by peer and sibling bullying and victimisation. In this study, we also found that peer and sibling bullying are related to physical and psychosomatic problems. Thus, functional impairment could be due to bullying involvement also that is confounded with the previous traumas they have experienced.

Alternatively, it was clear from the refugee charities that there are a number of interventions introduced to the refugee children during their after-school activities. Hence one can argue that such intervention or programs might have had a positive overall effect on children's satisfaction with life. One of the main principles of these charities is to compensate for the differences (e.g., educational or psychological) that might exist between refugee children and British born children. Both charities follow a mentoring scheme that offers children the chance to be monitored by an adult who helps them with their difficulties and advises them accordingly. Also, both run an integration program where they attempt to integrate children 
in social activities with other children and one charity focuses on psychological wellbeing through their mental health advocacy program. Such an intervention is highly recommended in the context of refugee children since this study has also revealed that the refugee status predicted several issues and difficulties in these children, namely peer problems, emotional issues, low school academic self-esteem, physical health problems and also, functional impairment. Work with refugee children should thus focus on skills on how to form and strengthen their friendship and on equipping them on how to deal with bullying.

Theoretical framework: According to the ecological theory no one single factor can explain why some people or groups are at higher risk of having more psychological or behavioural problems, while others are not. It views these factors as the outcome of interaction among many factors at different levels: the individual characteristics, the proximal relationship (direct relationship between the child and the immediate environment), and the distal community, and the societal (indirectly related to the child). Among these factors are personal characteristics (e.g., age, gender), emotional, behavioural and health status, socio-psychological factors, a history of behaving aggressively, and educational factors including the schooling system and policies. In our study we found that individual factors as well as factors that are related to relationships at home (with siblings) and at school (with peers) as well as the school and/or community investment (after school club) could affect the results in relation to refugees. We were also able to consider the effect of gender and age.

In this socio-psychological and educational ecological framework, the interaction with new networks or systems of relationships, that surround the child (factors and domains) (Bronfenbrenner, 2009) could affect their development (Bridge, Judd \& Moock, 1979). These domains represent a set of factors and variables such as individual factors (e.g., 
psychological factors), family practices (proximal), and environmental variables (distal: e.g., SES) (Bronfenbrenner \& Morris, 1998).

Thus, understanding the differences between refugees and the control group within such an ecological model may give us an insight into the most important factors that could improve refugees' psychological and behavioural well-being and integrate better within the schooling and cultural system.

This model is also useful for identifying suitable intervention strategies based on the ecological level in which they act explicitly for specific school type, specific age and specific problems. Therefore, educational professionals, schooling systems and policy makers could take these into account when they plan to build a multilevel program for refugees. In addition, according to the theory of educational productivity by Walberg (1981), which looks at different aspects and domains that affect the end outcomes differently, interventions according to this theory could consider the characteristics of the targeted children and adolescents such as their age and developmental level (e.g., abilities, prior achievements and motivation), and aspects of the educational and psychosocial environment including peer group, home environment, classroom climate and instructions characteristics (Walberg, 1981).

As is the case in our study it is important to note that from those who are coming from disadvantaged and deprived environments some children develop resiliency (Garmezy, 1993) and are able to have better outcomes, motivation, performance and achievement (Gutman, Sameroff \& Eccles, 2002). Similar to the ecological theory, a variety of factors could help children to bounce back (Wachs, 2000) including cognitive, social and educational abilities, the existence of supportive environment from parents, siblings, peers and schools (Gutman, Sameroff \& Cole, 2003).

In addition, negative bullying or victimization experiences in childhood or adolescence have 
an impact on psychological functioning later in life (Nansel et al., 2001; Wigderson \& Lunch, 2013). Despite a wealth of research on the psychological impact of bullying behaviours, previous research did not consider bullying behaviour including all types and taking into account sibling bullying as we did and there is a paucity of research on the specific impact of bullying in this area. A recent study by Busch et al. (2014) concluded that bullying affected academic performance if it caused psychosocial problems. Psychological health and selfesteem are key aspects to educational attainment. It is anticipated that poor psychological health will lead to lower aspirations because of its association with poor motivation, lack of energy and reduced expectations (Rothon, Arephin, Klineberg, Cattell \& Stansfeld, 2011). Thus, educational and health professionals, schools and governmental policies should build programs to tackle bullying (El Asam \& Samara, 2016; Smith et al., 2008; 2012; Samara \& Smith, 2008; Smith \& Samara, 2003; Foody \& Samara, 2018). Health practitioners (e.g., psychologists and doctors) should also take into account bullying by peers and siblings with its different forms and subgroups when assessing psychopathology amongst children and adolescents as these could be affected by victimisation (Samara, Burbidge, El Asam, Foody, Smith, \& Morsi, 2017).

\section{Limitations of the current study}

Given the relatively small sample size, one needs to be cautious about the generalisability of findings to populations. Moreover, since the intervention schemes in the form of mentoring and afterschool activities investigated in this study were only from two charities, future research needs to probe further into other existing intervention schemes in relation to the well-being of refugee children in the UK. This is essential in order to facilitate the integration of these children in a school environment that is highly supportive (Matthews, 2008).

Theoretically, it is anticipated that a sense of belonging at school can foster more attachment, commitment, integration as well as trust in the educational environment (Wehlage et al., 
1989). It is also essential to draw attention to the need for more efficient interventions to protect the emotional and psychological health of refugees (Peltonen, \& Punamäki, 2010). In order to boost school-academic self-esteem, it is of utmost importance to promote a collaborative relationship between schools and families. Based on past research, there are some interventions other than mentoring which aimed to achieve the above and have also proved to be successful; for instance, staff training (Strauss \& Smedley, 2009), home visits by school staff (Sanders, 2008) and homework clubs (Australian Refugee Association, 2009). However, these still need to be further promoted and implemented across the globe, including in the UK. Other variables that would require more attention in the future to help increase our understanding of this topic are the length of time the participants have lived in UK, the status of the younger refugee children: information about trauma history, daily stressors in the UK, immigration status and their parents' education. Consideration of these variables as potential influencing factors in future research could help towards a better understanding of wellbeing differential outcomes between refugee and non-refugee children. It is possible that age is associated with time in the UK and thus we can speculate that differences between younger and older refugee children may be due to this, however, to reach a firm conclusion on this information about time since migration is needed.

One of the limitations of the study is that the older refugee children group was compared also to a younger control group and not to an equivalent age group. Thus, it is harder to interpret these results because these groups differ on refugee status, age, and method of measurement (self-report vs. parental report). However, the existence of the older refugee group gave another insight into age differences between older and younger refugee children in comparison, to a control group. Also, there were some common differences between the refugee children (younger and older) and the control group such as physical health. 
Another issue is related to the reliability of some of the SDQ subscales, which were different between the self and the parental reports. Specifically, the reliabilities were higher for parental reports on hyperactivity, conduct and peer problems and slightly higher for selfreports on total and emotional scales. This may indicate that parents are more aware of the extent of externalising problems compared to their children, while children are more aware of the internalising problems and their impact on their daily life activities.

Unlike this study, many studies on refugees chose to focus on homogeneous refugee samples (e.g., Hunt \& Gakenyi, 2005; Kroll, Yusuf, \& Fujiwara, 2011; Silove et al., 2007). An untested assumption remains that a homogeneous sample could have yielded results different from the current study since the individuals would share a more or less similar cultural and/or historical background, hence laying a strong foundation for the generation of causal explanations of psychological distress or even further interventions. From a methodological point of view, since the questionnaires used in this research did not incorporate a qualitative section, detailed insight into how these children were affected by their experiences was not gained (Berman, 2001).

\section{Conclusions and Implications}

Our results demonstrate that the refugee children were to some extent vulnerable as they experienced several adverse consequences of being a refugee. However, in contradiction with previous findings pointing to the various issues encountered by younger refugee children, refugee children in the current study did not score significantly in terms of PTSD, a decline in life satisfaction and peer bullying, which may have been due to the role of the afterschool clubs.

This study emphasised the roles played by after-school clubs in promoting the wellbeing of refugee children; especially with the support of teachers to ensure that these children make the most of these support services (Szente, Hoot, \& Taylor, 2006). In line with past research 
highlighting the positive effect of these after-school clubs on the development of friendships (Candappa \& Ahmad, 2007) and their safeguarding on a social and emotional level (Halpern, 2000), schools should further consider the inclusion of these clubs in their curriculum to support refugee children. This is essential as until quite recently, some concerns have been raised that research on how schools can 'care' for these refugee children is still scant (Due \& Riggs, 2016). Current findings based on after-school clubs as support programmes for younger refugee children imply that this is an area which should be further examined on both a theoretical and practical level. Future studies may also include data from refugee children who do not have access to afterschool clubs to examine differences.

In a nutshell, the current findings identify some areas of difficulty in refugee children; however, after adjusting for friendship quality, bullying/victimisation or number of friends most of these differences no longer exist. This suggests that positive peer relationships can explain these difficulties and could better promote the wellbeing of refugee children. Bearing in mind that in terms of PTSD symptoms, conduct, emotional and hyperactivity problems, refugee children did not show difficulties. This reflects some level of resilience in these children across these domains. However, physical health was significantly worse in refugee children and as such, addressing medical problems should also be a priority. With all the above in mind and in support of Fazel et al. (2012), this study points towards a pressing need for host countries to work towards the implementation of adequate immigration, health-care, and social policies that are powerful and effective enough to support refugee families and hence limit damaging consequences for child health and development. Schools should also play their part by building programs to support refugees, as well as other vulnerable children, including protecting them from bullying and helping them to integrate them into the school community. 


\section{References}

Almqvist, K., \& Brandell-Forsberg, M. (1997). Refugee children in Sweden: Post-traumatic stress disorder in Iranian preschool children exposed to organized violence. Child Abuse \& Neglect, 21(4), 351-366.

Australian Refugee Association, (2009). Homework clubs chalking up success, Australian Refugee Association, Underdale, SA.

Berman, H. (2001). Children and war: Current understandings and future directions. Public Health Nursing, 18(4), 243-252.

Betancourt, T. S., Abdi, S., Ito, B. S., Lilienthal, G. M., Agalab, N., \& Ellis, H. (2015). We left one war and came to another: Resource loss, acculturative stress, and caregiver-child relationships in Somali refugee families. Cultural Diversity and Ethnic Minority Psychology, 21, 114.

Bolger, K. E., Patterson, C. J., \& Kupersmidt, J. B. (1998). Peer relationships and self-esteem among children who have been maltreated. Child Development, 69,1171-1197.

Bollmer, J. M., Milich, R., Harris, M. J., \& Maras, M. A. (2005). A friend in need the role of friendship quality as a protective factor in peer victimization and bullying. Journal of Interpersonal Violence, 20(6), 701-712.

Breslau, N., Wilcox, H. C., Storr, C. L., Lucia, V. C., \& Anthony, J. C. (2004). Trauma exposure and posttraumatic stress disorder: A study of youths in urban America. Journal of Urban Health, 81(4), 530-544.

Bridges, R. G., Judd, C. M., \& Moock, P. R. (1979). The Determinants of Educational Outcomes: The Impact of Families, Peers, Teachers, and Schools. Cambridge, MA: Ballinger.

Bronfenbrenner U. (2009). The ecology of human development: Experiments by nature and design: Harvard university press. 
Bronfenbrenner, U., \& Morris P. A. (1998). The ecology of developmental processes. Handbook of child psychology, 1, 993-1028.

Bronstein, I., \& Montgomery, P. (2011). Psychological distress in refugee children: A systematic review. Clinical Child and Family Psychology Review, 14(1), 44-56.

Bronstein, I., Montgomery, P., \& Dobrowolski, S. (2012). PTSD in asylum-seeking male adolescents from Afghanistan. Journal of Traumatic Stress, 25(5), 551-557.

Buhs, E. S., \& Ladd, G. W. (2001). Peer rejection as antecedent of young children's school adjustment: An examination of mediating processes. Developmental Psychology, 37(4), 550.

Busch, V., Loyen, A., Lodder, M., Schrijvers, A. J., van Yperen, T. A., \& de Leeuw, J. R. (2014). The Effects of Adolescent Health-Related Behavior on Academic Performance A Systematic Review of the Longitudinal Evidence. Review of Educational Research. 0034654313518441.

Candappa, M., \& Ahmad, M. (2007). Education and schooling for asylum-seeking and refugee students in Scotland: An exploratory study.

Carswell, K., Blackburn, P., \& Barker, C. (2011). The relationship between trauma, postmigration problems and the psychological well-being of refugees and asylum seekers. International Journal of Social Psychiatry, 57, 107-119.

Closs, A., Stead, J., Arshad, R., \& Norris, C. (2001). School peer relationships of 'minority' children in Scotland. Child: Care, health and development, 27(2), 133-148.

Coie, J. D., \& Dodge, K. A. (1983). Continuities and changes in children's social status: A five-year longitudinal study. Merrill-Palmer Quarterly, 29, 261- 281.

Cole, E., \& Brown, R. S. (2002). Psychological Needs of Post-War Children in Kosovo A Preliminary Analysis. School Psychology International, 23(2), 131-147.

Coopersmith, S. (1981). SEI, Self-esteem Inventories. Consulting Psychologist Press. 
Correa-Velez, I., Gifford, S. M., \& Barnett, A. G. (2010). Longing to belong: Social inclusion and wellbeing among youth with refugee backgrounds in the first three years in Melbourne, Australia. Social Science and Medicine, 71, 1399-1408.

Derluyn, I. (2005). Emotional and behavioural problems in unaccompanied refugee minors. Orthopedagogische Reeks, 19, 1-253.

Derluyn, I., \& Broekaert, E. (2007). Different perspectives on emotional and behavioural problems in unaccompanied refugee children and adolescents, Ethnicity and Health, 12, $141-162$.

Derluyn, I., Broekaert, E., \& Mels, C. (2008). Social support in unaccompanied asylum-seeking boys: A case study. Child: Care, Health and Development, 34(6), 757762.

Diener, E. D., Emmons, R. A., Larsen, R. J., \& Griffin, S. (1985). The satisfaction with life scale. Journal of Personality Assessment, 49(1), 71-75.

Dimitry, L. (2012). A systematic review on the mental health of children and adolescents in areas of armed conflict in the Middle East. Child: Care, Health and Development, 38, 153-161.

Dodds, A. E., Lawrence, J. A., Karantzas, K., Brooker, A., Lin, Y. H., Champness, V., \& Albert, N. (2010). Children of Somali refugees in Australian schools: Self-descriptions of school-related skills and needs. International Journal of Behavioral Development, 34(6), $521-528$.

Due, C., \& Riggs, D. W. (2016). Care for children with migrant or refugee backgrounds in the school context. Children Australia, 41(3), 190-200.

Dunkerley, D., Scourfield, J., Maegusuku-Hewett, T., \& Smalley, N. (2006). Children seeking asylum in Wales. Journal of Refugee Studies, 19, 488-508. 
Ehntholt, K. A., \& Yule, W. (2006). Practitioner review: Assessment and treatment of refugee children and adolescents who have experienced war-related trauma. Journal of Child Psychology and Psychiatry, 47(12), 1197-1210.

El Asam, A., \& Samara, M. (2016). Cyberbullying and the law: A review of psychological and legal challenges. Computers in Human Behaviour, 65, 127-141.

Fandrem, H., Strohmeier, D., \& Roland, E. (2009). Bullying and victimization among native and immigrant adolescents in Norway the role of proactive and reactive aggressiveness. The Journal of Early Adolescence, 29(6), 898-923.

Fangen, K. (2006). Humiliation experienced by Somali refugees in Norway. Journal of Refugee Studies, 19(1), 69-93.

Fazel, M., \& Stein, A. (2003). Mental health of refugee children: Comparative study. British Medical Journal, 327(7407), 134-134.

Fazel, M., Reed, R. V., Panter-Brick, C., \& Stein, A. (2012). Mental health of displaced and refugee children resettled in high-income countries: Risk and protective factors. The Lancet, 379(9812), 266-282.

Foa, E. B., Johnson, K. M., Feeny, N. C., \& Treadwell, K. R. (2001). The Child PTSD Symptom Scale: A preliminary examination of its psychometric properties. Journal of Clinical Child Psychology, 30(3), 376-384.

Foody, M. \& Samara, M. (2018). Considering mindfulness techniques in school-based antibullying programmes. Journal of New Approaches in Educational Research (NAER), 7(1), 3-9. https://doi.org/10.7821/naer.2018.1.253

Fordham, K., \& Stevenson-Hinde, J. (1999). Shyness, friendship quality, and adjustment during middle childhood. Journal of Child Psychology and Psychiatry, 40(5), 757-768.

Furlong, M. J., Sharma, B., \& Rhee, S. S. (2000). Defining school violence victim subtypes: A step toward adapting prevention and intervention programs to match student needs. In 
D. S. Sandhu \& C. B. Aspey (Eds.), Violence in American schools (pp. 69-85).

Alexandria, VA: American Counseling Association.

Gadermann, A. M., Schonert-Reichl, K. A., \& Zumbo, B. D. (2010). Investigating validity evidence of the satisfaction with life scale adapted for children. Social Indicators Research, 96(2), 229-247.

Garmezy, N. (1993) Children in poverty: Resilience despite risk. Psychiatry, 56(1), 127-136.

Goodman, R., Bourdon, K. H., Rae, D. S., Simpson, G., \& Koretz, D. S. (2005). The Strengths and Difficulties Questionnaire: US normative data and psychometric properties. Journal of the American Academy of Child \& Adolescent Psychiatry, 44(6), 557-564.

Goodyer, I. M., Wright, C., \& Altham, P. M. E. (1989). Recent friendships in anxious and depressed school age children. Psychological medicine, 19(01), 165-174.

Goodyer, I., Wright, C., \& Altham, P. (1990). The friendships and recent life events of anxious and depressed school-age children. The British Journal of Psychiatry, 156(5), 689-698.

Gullone, E., \& Cummins, R.A. (1999). The comprehensive quality of Life Scale: A psychometric evaluation with an adolescent sample. Behavior Change, 16, 127-139.

Gutman, L. M., Sameroff, A. J., \& Eccles, J. S. (2002). The academic achievement of African American students during early adolescence: An examination of multiple risk, promotive, and protective factors. American journal of community psychology, 30(3), 367-399.

Gutman, L. M., Sameroff, A. J., Cole, R. (2003). Academic growth curve trajectories from 1st grade to 12th grade: Effects of multiple social risk factors and preschool child factors. Developmental Psychology, 39, 777-790.

Halpern, R. (2000). The promise of after-school programs for low-income children. Early Childhood Research Quarterly, 15(2), 185-214. 
Hamilton, R. (2003). Schools, teachers and the education of refugee children. In Educational interventions for refugee children (pp. 97-110). Routledge.

Hamilton, R. J., \& Moore, D. (Eds.). (2004). Educational interventions for refugee children: Theoretical perspectives and implementing best practice. Psychology Press.

Hansen, D. J., Giacoletti, A. M., \& Nangie, D. W. (1995). Social interactions and adjustment. In V. B. Van Hasselt \& M. Hersen (Eds.), Handbook of adolescent psychopathology: A guide to diagnosis and treatment. New York: Lexington Books.

Hartup, W. W. (1993). Adolescents and their friends. In B. Laursen (Ed.), New directions for child development: No. 60. Close friendships in adolescence (pp. 2-22). San Fransisco: JosseyBass Inc.

Hartup, W.W., \& Stevens, N. (1999). Friendships and adaptation across the life span. Current Directions in Psychological Science, 8, 76-79.

Hek, R. (2005). The role of education in the settlement of young refugees in the UK: The experiences of young refugees. Practice, 17, 157-171.

Hek, R. (2005). The role of education in the settlement of young refugees in the UK: The experiences of young refugees. Practice, 17(3), 157-171.

Hodes, M. (1998). Refugee children: May need a lot of psychiatric help. British Medical Journal, 316, 793-794.

Hodes, M. (2000). Psychologically distressed refugee children in the United Kingdom. Child Psychology and Psychiatry Review, 5(2), 57-68.

Hodes, M. (2002). Implications for psychiatric services of chronic civilian strife: young refugees in the UK. Advances in Psychiatric Treatment, 8(5), 366-374.

Hodes, M., \& Tolmac, J. (2005). Severely impaired young refugees. Clinical Child Psychology and Psychiatry, 10(2), 251-261. 
Hodes, M., Jagdev, D., Chandra, N., \& Cunniff, A. (2008). Risk and resilience for psychological distress amongst unaccompanied asylum seeking adolescents. Journal of Child Psychology and Psychiatry, 49(7), 723-732.

Hodges, E. V. E., Boivin, M., Vitaro, F., \& Bukowski, W. M. (1999). The power of friendship: Protection against an escalating cycle of peer victimization. Developmental Psychology, 75, 94-101.

Hope, J. (2008). “One day we had to run": The development of the refugee identity in children's literature and its function in education. Children's Literature in Education, 39, 295-304.

Howard, M., \& Hodes, M. (2000). Psychopathology, adversity, and service utilization of young refugees. Journal of the American Academy of Child and Adolescent Psychiatry, 39(3), 368-377.

Hunt, N., \& Gakenyi, M. (2005). Comparing refugees and nonrefugees: The Bosnian experience. Journal of Anxiety Disorders, 19(6), 717-723.

Juvonen, J., Graham, S., \& Schuster, M. A. (2003). Bullying among young adolescents: The strong, the weak, and the troubled. Pediatrics, 112(6), 1231-1237.

Kroll, J., Yusuf, A. I., \& Fujiwara, K. (2011). Psychoses, PTSD, and depression in Somali refugees in Minnesota. Social Psychiatry and Psychiatric Epidemiology, 46(6), 481-493.

Lustig, S. L., Kia-Keating, M., Knight, W. G., Geltman, P., Ellis, H., Kinzie, J. D., ... \& Saxe, G. N. (2004). Review of child and adolescent refugee mental health. Journal of the American Academy of Child and Adolescent Psychiatry, 43(1), 24-36.

Mann, G. (2010). 'Finding a life' among undocumented Congolese refugee children in Tanzania. Children and Society, 24, 261-270.

Matthews, J. (2008). Schooling and settlement: Refugee education in Australia. International studies in sociology of education, 18(1), 31-45. 
McKenney, K. S., Pepler, D., Craig, W., \& Connolly, J. (2006). Peer victimization and psychosocial adjustment: The experiences of Canadian immigrant youth. Electronic Journal of Research in Educational Psychology, 9(4), 239-264.

Monks, C. P., Ortega-Ruiz, R., \& Rodríguez-Hidalgo, A. J. (2008). Peer victimization in multicultural schools in Spain and England. European Journal of Developmental Psychology, 5(4), 507-535.

Montgomery, E., \& Foldspang, A. (2005). Seeking asylum in Denmark: Refugee children's mental health and exposure to violence. The European Journal of Public Health, 15(3), 233-237.

Nansel, T. R., Overpeck, M., Pilla, R. S., Ruan, W. J., Simons-Morton, B., \& Scheidt, P. (2001). Bullying behaviors among US youth: Prevalence and association with psychosocial adjustment. JAMA, 285(16), 2094-2100.

Orth, U., Erol, R. Y., \& Luciano, E. C. (2018). Development of self-esteem from age 4 to 94 years: A meta-analysis of longitudinal studies. Psychological Bulletin, 144(10), 10451080.

Peltonen, K., \& Punamäki, R. L. (2010). Preventive interventions among children exposed to trauma of armed conflict: A literature review. Aggressive behavior, 36, 95-116.

Peltonen, K., Qouta, S., El Sarraj, E., \& Punamäki, R. L. (2010). Military trauma and social development: The moderating and mediating roles of peer and sibling relations in mental health. International Journal of Behavioral Development, 34, 554-563.

Peltonen, K., Qouta, S., El Sarraj, E., \& Punamäki, R. L. (2012). Effectiveness of schoolbased intervention in enhancing mental health and social functioning among war-affected children. Traumatology: An International Journal, 18(4), 37-46.

Richman, N. (1998). Looking before and after: Refugees and asylum seekers in the West. Rethinking the trauma of war, 170-186. 
Rothe, E. M., Lewis, J., Castillo-Matos, H., Martinez, O., Busquets, R. \& Martinez, I. (2002). Post traumatic stress disorder in Cuban children and adolescents after release from a refugee camp. Psychiatric Services, 53(8), 970-976.

Rothon, C., Arephin, M., Klineberg, E., Cattell, V., \& Stansfeld, S. (2011). Structural and socio-psychological influences on adolescents' educational aspirations and subsequent academic achievement. Social Psychology of Education, 14(2), 209-231.

Roy, P., Rutter, M., \& Pickles, A. (2004). Institutional care: Associations between overactivity and lack of selectivity in social relationships. Journal of Child Psychology and Psychiatry, 45, 866-873.

Rubin, K. H., Dwyer, K. M., Booth-LaForce, C., Kim, A. H., Burgess, RoseKrasnor, L. (2004). Attachment, friendship, and psychosocial functioning in early adolescence. Journal of Early Adolescence, 24, 326-356.

Samara, M., \& Smith, P. K. (2008). How schools tackle bullying, and the use of whole school policies: changes over the last decade. Educational Psychology, 28(6), 663 - 676.

Samara, M., Burbidge, V., El Asam, A., Foody, M., Smith, P.K., \& Morsi, H. (2017). Bullying and Cyberbullying: Their Legal Status and Use in Psychological Assessment. International Journal of Environmental Research and Public Health, 14(12), 1449. doi:10.3390/ijerph14121449

Savin-Williams, R. C., \& Berndt, T. J. (1990). Friendship and peer relations. In S. Feldman \& G. R. Elliot (Eds.), At the threshold: The developing adolescent. Cambridge, MA: Harvard University Press.

Scales, P. C., Roehlkepartain, E. C., Wallace, T., Inselman, A., Stephenson, P., \& Rodriguez, M. (2015). Brief report: Assessing youth well-being in global emergency settings: Early results from the Emergency Developmental Assets Profile. Journal of adolescence, 45, 98 102. 
Servan-Schreiber, D., Lin, B. L., \& Birmaher, B. (1998). Prevalence of posttraumatic stress disorder and major depressive disorder in Tibetan refugee children. Journal of the American Academy of Child \& Adolescent Psychiatry, 37(8), 874-879.

Schafer, M., Korn, S., Brodbeck, F. C., Wolke, D., \& Schulz, H. (2005). Bullying roles in changing contexts: The stability of victim and bully roles from primary to secondary school. International Journal of Behavioral Development, 29, 323-335.

Scheithauer, H., Smith, P. K. \& Samara, M. (2016). Cultural Issues in Bullying and Cyberbullying among Children and Adolescents: Methodological Approaches for Comparative Research. International Journal of Developmental Science 10, 3-8. DOI 10.3233/DEV-16000085.

Shallow, N., \& Whitington, V. (2014). The wellbeing of refugee children in an early childhood education context: connections and dilemmas. The Journal of Educational Enquiry, 13(1).

Silove, D., Steel, Z., Bauman, A., Chey, T., \& McFarlane, A. (2007). Trauma, PTSD and the longer-term mental health burden amongst Vietnamese refugees. Social Psychiatry and Psychiatric Epidemiology, 42(6), 467-476.

Sirin, S. R., \& Rogers-Sirin, L. (2015). The educational and mental health needs of Syrian refugee children. Washington, DC: Migration Policy Institute.

Smith, P. K., \& Samara M. (2003). Evaluation of the DfES anti bullying pack. London: DfES. Smith, P. K., Kupferberg, A., Mora-Merchan, J. A., Samara, M., Bosley, S., \& Osborn, R. A. (2012). Content analysis of school anti-bullying policies: A follow-up after six years. Educational Psychology in Practice. 28(1), 47-70.

Smith, P. K., Smith, C., Osborn, R., Samara, M. (2008). A content analysis of school antibullying policies: progress and limitations. Educational Psychology in Practice, 24(1), 112. 
Stanley, K. (2001). Cold comfort: Young separated refugees in England. London: Save the Children.

Strauss, P., \& Smedley, F. (2009). Welcoming Refugee Students into New Zealand Schools. New Zealand Journal of Educational Studies, 44(2), 3.

Szente, J., Hoot, J., \& Taylor, D. (2006). Responding to the special needs of refugee children: Practical ideas for teachers. Early Childhood Education Journal, 34(1), 15-20.

Tabachnik, B. G., \& Fidell, L. S. (1989). Using multivariate statistics (2nd edn). New York: Harper and Row.

Thabet, A. A. M., Abed, Y., \& Vostanis, P. (2004). Comorbidity of PTSD and depression among refugee children during war conflict. Journal of Child Psychology and Psychiatry, 45(3), 533-542.

Tyrer, R. A., \& Fazel, M. (2014). School and community-based interventions for refugee and asylum seeking children: A systematic review. PloS one, 9(2), e89359.

Ugwuegbu, D., \& Temowo, A. O. (1995). Psychosocial variables as determinants of neuroticism among refugees in Nigeria. African Journal for the Psychological Study of Social Issues, 2, 1-2.

United Nations High Commissioner for Refugees, Global Trends, (2018). Figures at a glance. Retrieved from http://www.unhcr.org/uk/figures-at-a-glance.html.

Wachs, T. D. (2000). Necessary but not sufficient: The respective roles of single and multiple influences on individual development: American Psychological Association.

Walberg, H. J., Haertel, G. D., Pascarella, E., Junker, L. K., \& Boulanger, F. D. (1981). Probing a model of educational productivity in science with national assessment samples of early adolescents. American Educational Research Journal. 18(2), 233-249. 
Watkins, P. G., Razee, H., \& Richters, J. (2012). 'I'm Telling You... The Language Barrier is the Most, the Biggest Challenge': Barriers to Education among Karen Refugee Women in Australia. Australian Journal of Education, 56(2), 126-141.

Way, N., \& Greene, M. (2005, March). Exploring adolescents' perceptions of parental attitudes and rules about friendships. Paper presented at Biennial meeting of the Society for Research on Child Development.

Wehlage, G. G., Rutter, R. A., Smith, G. A., \& Lesko, N. 8c Fernandez, RR (1989). Reducing the risk: Schools as communities of support.

Wigderson, S., \& Lynch, M. (2013). Cyber-and traditional peer victimization: Unique relationships with adolescent well-being. Psychology of Violence, 3(4), 297.

Wolke, D., \& Samara, M. M. (2004). Bullied by siblings: Association with peer victimisation and behaviour problems in Israeli lower secondary school children. Journal of Child Psychology and Psychiatry, 45(5), 1015-1029.

Wolke, D., Woods, S., Bloomfield, L., \& Karstadt, L. (2000). The association between direct and relational bullying and behaviour problems among primary school children. Journal of Child Psychology and Psychiatry, 41(8), 989-1002.

Wolke, D., Woods, S., Samara, M. (2009). Who escapes or remains a victim of bullying in primary school? British Journal of Developmental Psychology 27, 835-851.

Worthington, D. M. (2001). Access to information about government services among culturally and linguistically diverse audiences. Victorian Department of Premier and Cabinet: Melbourne.

Yale University. (2017, June 15). New tool measures resilience in adolescent Syrian refugees. ScienceDaily. Retrieved January 18, 2018 from www.sciencedaily.com/releases/2017/06/170615213304.htm 
Table 1: Mean and Standard Deviation (SD) across groups and differences using Analysis of Variance (F) and the Effect Size $\left(\eta^{2}\right)$

\begin{tabular}{|c|c|c|c|c|c|}
\hline & $\begin{array}{l}\text { Control } \\
\text { Group }\end{array}$ & $\begin{array}{c}\text { Younger } \\
\text { Refugee } \\
\text { Children } \\
\text { Group }\end{array}$ & $\begin{array}{c}\text { Older } \\
\text { Refugee } \\
\text { Children } \\
\text { Group }\end{array}$ & $\mathbf{F}$ & $\eta^{2}$ \\
\hline Number of siblings & $1.54(1.38)$ & $2.58(1.59)$ & $3.97(3.82)$ & $23.813 * *$ & .211 \\
\hline Satisfaction with Life & $27.01(6.69)$ & $26.19(6.71)$ & $25.04(6.93)$ & 1.456 & .179 \\
\hline \multicolumn{6}{|l|}{ Friendship } \\
\hline Number of friends & $3.45(1.47)$ & $4.62(0.86)$ & $4.89(0.37)$ & $38.171 * *$ & .438 \\
\hline Number of best friends & $3.04(1.50)$ & $3.04(1.85)$ & $3.20(1.77)$ & 0.169 & .005 \\
\hline Friendship Quality & $10.41(3.00)$ & $10.32(3.88)$ & $11.21(2.70)$ & 1.564 & .027 \\
\hline \multicolumn{6}{|l|}{ Self-Esteem } \\
\hline School Academic & $4.30(1.62)$ & $4.13(1.68)$ & $3.51(1.26)$ & $5.106 * *$ & .110 \\
\hline General Self-esteem & $15.80(4.73)$ & $16.27(6.46)$ & $18.44(5.08)$ & $4.65 *$ & .020 \\
\hline Social Self Peers & $3.96(1.53)$ & $4.35(1.70)$ & $3.61(1.13)$ & $4.475^{*}$ & .124 \\
\hline Home Parents & $4.30(1.51)$ & $4.27(1.52)$ & $4.13(1.33)$ & 0.266 & .009 \\
\hline Total Self- Esteem & $28.35(5.68)$ & $28.96(8.54)$ & $29.70(5.14)$ & 0.722 & .015 \\
\hline \multicolumn{6}{|l|}{ SDQ } \\
\hline Emotional Symptoms & $2.59(2.12)$ & $3.35(2.79)$ & $3.35(2.61)$ & 2.395 & .036 \\
\hline Conduct Problems & $2.45(2.25)$ & $2.90(2.41)$ & $2.89(1.94)$ & 0.992 & .020 \\
\hline Hyperactivity & $3.86(2.50)$ & $3.48(2.01)$ & $3.80(2.14)$ & 0.479 & .006 \\
\hline Peer Problems & $2.10(2.15)$ & $3.65(2.25)$ & $2.26(1.88)$ & $9.572 * *$ & .206 \\
\hline Prosocial behaviour & $7.56(2.10)$ & $7.30(2.77)$ & $7.35(2.25)$ & 0.252 & .023 \\
\hline SDQ - Total & $11.00(7.23)$ & $13.19(7.46)$ & $12.30(6.51)$ & 1.689 & .059 \\
\hline \multicolumn{6}{|l|}{ Difficulties } \\
\hline \multicolumn{6}{|l|}{ PTSD } \\
\hline Re-experiencing & $3.75(2.84)$ & $5.43(3.86)$ & $4.50(3.69)$ & 1.913 & .034 \\
\hline Avoidance & $5.72(4.41)$ & $5.83(5.09)$ & $5.44(5.22)$ & 0.064 & .023 \\
\hline Hypervigilance & $4.38(3.17)$ & $4.71(4.12)$ & $3.93(3.95)$ & 0.403 & .053 \\
\hline Overall PTSD & $13.84(9.16)$ & $15.83(11.31)$ & $13.57(11.49)$ & 0.477 & .043 \\
\hline Functional Impairment & $1.38(1.66)$ & $4.47(2.37)$ & $2.44(2.56)$ & $15.124 * *$ & .251 \\
\hline \multicolumn{6}{|l|}{ Health } \\
\hline Psychosomatic health & $4.92(3.71)$ & $6.00(5.24)$ & $5.19(4.62)$ & 1.15 & .016 \\
\hline Physical health & $7.95(6.72)$ & $11.94(9.18)$ & $12.58(8.53)$ & $7.831 * *$ & .037 \\
\hline
\end{tabular}

$* \mathrm{P}<0.05,{ }^{*} \mathrm{p}<0.01$ 
Table 2. Frequency and percentage (\%) according to the types and subgroups of bullying by peers and siblings by groups (younger and older refugee groups and control group).

\begin{tabular}{|c|c|c|c|c|c|c|}
\hline & Group & Neutral & Victim & Bully & Bully/Victim & Total \\
\hline \multirow{3}{*}{$\begin{array}{l}\text { Peer } \\
\text { Direct }\end{array}$} & Control & $58(49.6 \%)$ & $35(29.9 \%)$ & $6(5.1 \%)$ & $18(15.4 \%)$ & 117 \\
\hline & $\begin{array}{l}\text { Younger } \\
\text { Refugee } \\
\text { Children }\end{array}$ & $34(46.6 \%)$ & $25(34.2 \%)$ & $0(0.0 \%)$ & $14(19.2 \%)$ & 73 \\
\hline & $\begin{array}{l}\text { Older Refugee } \\
\text { children }\end{array}$ & $48(70.6 \%)$ & $9(13.2 \%)$ & $6(8.8 \%)$ & $5(7.4 \%)$ & 68 \\
\hline \multirow{3}{*}{$\begin{array}{l}\text { Peer } \\
\text { Relational }\end{array}$} & Control & $58(49.6 \%)$ & $39(33.3 \%)$ & $5(4.3 \%)$ & $15(12.8 \%)$ & 117 \\
\hline & $\begin{array}{l}\text { Younger } \\
\text { Refugee } \\
\text { Children }\end{array}$ & $31(42.5 \%)$ & $30(41.1 \%)$ & $2(2.7 \%)$ & $10(13.7 \%)$ & 73 \\
\hline & $\begin{array}{l}\text { Older Refugee } \\
\text { Children }\end{array}$ & $55(80.9 \%)$ & $7(10.3 \%$ & $4(5.9 \%)$ & $2(2.9 \%$ & 68 \\
\hline \multirow{3}{*}{$\begin{array}{l}\text { Overall } \\
\text { Peer }\end{array}$} & Control & $43(36.8 \%)$ & $40(34.2 \%$ & $5(4.3 \%)$ & $29(24.8 \%)$ & 117 \\
\hline & $\begin{array}{l}\text { Younger } \\
\text { Refugee } \\
\text { Children }\end{array}$ & $26(35.6 \%)$ & $31(42.5 \%$ & $0(0.0 \%$ & $16(21.9 \%)$ & 73 \\
\hline & $\begin{array}{l}\text { Older Refugee } \\
\text { Children }\end{array}$ & $45(66.2 \%)$ & $11(16.2 \%$ & $6(8.8 \%)$ & $6(8.8 \%)$ & 68 \\
\hline \multirow{3}{*}{$\begin{array}{l}\text { Sibling } \\
\text { Direct }\end{array}$} & Control & $32(33.0 \%)$ & $39(40.2 \%)$ & $6(6.2 \%)$ & $20(20.6 \%)$ & 97 \\
\hline & $\begin{array}{l}\text { Younger } \\
\text { Refugee } \\
\text { Children }\end{array}$ & $35(54.7 \%)$ & $13(20.3 \%)$ & $2(3.1 \%)$ & $14(21.9 \%)$ & 64 \\
\hline & $\begin{array}{l}\text { Older Refugee } \\
\text { Children }\end{array}$ & $51(75.0 \%)$ & $6(8.8 \%)$ & $1(1.5 \%)$ & $10(14.7 \%)$ & 68 \\
\hline \multirow{3}{*}{$\begin{array}{l}\text { Sibling } \\
\text { Relational }\end{array}$} & Control & $50(51.5 \%)$ & $26(26.8 \%)$ & $3(3.1 \%$ & $18(18.6 \%)$ & 97 \\
\hline & $\begin{array}{l}\text { Younger } \\
\text { Refugee } \\
\text { Children }\end{array}$ & $40(62.5 \%)$ & $13(20.3 \%)$ & $6(9.4 \%)$ & $5(7.8 \%)$ & 64 \\
\hline & $\begin{array}{l}\text { Older Refugee } \\
\text { Children }\end{array}$ & $55(80.9 \%)$ & $7(10.3 \%)$ & $3(4.4 \%)$ & $3(4.4 \%)$ & 68 \\
\hline \multirow{3}{*}{$\begin{array}{l}\text { Overall } \\
\text { Sibling }\end{array}$} & Control & $30(30.9 \%)$ & $34(35.1 \%)$ & $4(4.1 \%)$ & $29(29.9 \%)$ & 97 \\
\hline & $\begin{array}{l}\text { Younger } \\
\text { Refugee } \\
\text { Children }\end{array}$ & $30(46.9 \%)$ & $17(26.6 \%)$ & $3(4.7 \%)$ & $14(21.9 \%)$ & 64 \\
\hline & $\begin{array}{l}\text { Older Refugee } \\
\text { Children }\end{array}$ & $50(73.5 \%$ & $5(7.4 \%)$ & $1(1.5 \%$ & $12(17.6 \%)$ & 68 \\
\hline
\end{tabular}


Table 3. A series of linear regression analyses predicting behavioural and health problems outcomes by group type before and after adjusting for friendship quality, number of friends, peer bullying/victimisation or sibling bullying/victimisation (bold results became non-significant after adjustment) *.

\begin{tabular}{|c|c|c|c|c|c|c|c|}
\hline & & $\begin{array}{r}\text { Con } \\
\text { Younge } \\
\text { Chil }\end{array}$ & $\begin{array}{l}\text { l vs. } \\
\text { Refugee } \\
\text { n }^{* *}\end{array}$ & $\begin{array}{r}\text { Young I } \\
\text { OldeI } \\
\text { Chi }\end{array}$ & $\begin{array}{l}\text { Igees vs. } \\
\text { fugee } \\
n^{* *}\end{array}$ & $\begin{array}{r}\text { Cont } \\
\text { Older } \\
\text { Chil }\end{array}$ & $\begin{array}{l}\text { I vs. } \\
\text { fugee } \\
\text { en }^{* *}\end{array}$ \\
\hline & Predictors & B & Sig. & B & Sig. & B & Sig. \\
\hline School & Group only & & & -0.619 & 0.014 & -0.391 & 0.002 \\
\hline $\begin{array}{l}\text { Academic } \\
\text { Self-esteem }\end{array}$ & $\begin{array}{l}\text { Group (Adjusting } \\
\text { for friendship- } \\
\text { quality) }\end{array}$ & & & -0.632 & 0.014 & -0.426 & 0.001 \\
\hline & $\begin{array}{l}\text { Group (Adjusting } \\
\text { for number of } \\
\text { friends) }\end{array}$ & & & -0.417 & 0.131 & -0.373 & 0.020 \\
\hline & $\begin{array}{l}\text { Group (Adjusting } \\
\text { for overall peer } \\
\text { victim) }\end{array}$ & & & -0.298 & 0.275 & -0.264 & 0.050 \\
\hline & $\begin{array}{l}\text { Group (Adjusting } \\
\text { for overall peer } \\
\text { bully) }\end{array}$ & & & -0.559 & 0.034 & -0.343 & 0.006 \\
\hline & $\begin{array}{l}\text { Group (Adjusting } \\
\text { for overall sibling } \\
\text { victim) }\end{array}$ & & & -0.399 & 0.119 & -0.274 & 0.047 \\
\hline & $\begin{array}{l}\text { Group (Adjusting } \\
\text { for overall sibling } \\
\text { bully) }\end{array}$ & & & -0.543 & 0.034 & -0.370 & 0.006 \\
\hline General & Group only & & & 2.176 & 0.026 & 1.320 & 0.002 \\
\hline Self-esteem & $\begin{array}{l}\text { Group (Adjusting } \\
\text { for friendship- } \\
\text { quality) }\end{array}$ & & & 2.117 & 0.034 & 1.110 & 0.007 \\
\hline & $\begin{array}{l}\text { Group (Adjusting } \\
\text { for number of } \\
\text { friends) }\end{array}$ & & & 2.033 & 0.065 & 0.395 & 0.492 \\
\hline & $\begin{array}{l}\text { Group (Adjusting } \\
\text { for overall peer } \\
\text { victim) }\end{array}$ & & & 1.249 & 0.253 & 0.954 & 0.038 \\
\hline & $\begin{array}{l}\text { Group (Adjusting } \\
\text { for overall peer } \\
\text { bully) }\end{array}$ & & & 2.142 & 0.042 & 1.148 & 0.008 \\
\hline & $\begin{array}{l}\text { Group (Adjusting } \\
\text { for overall sibling } \\
\text { victim) }\end{array}$ & & & 2.016 & 0.061 & 1.198 & 0.012 \\
\hline & $\begin{array}{l}\text { Group (Adjusting } \\
\text { for overall sibling } \\
\text { bully) }\end{array}$ & & & 2.107 & 0.042 & 0.992 & 0.028 \\
\hline Physical & Group only & 3.994 & 0.002 & & & 2.316 & 0.000 \\
\hline health & Group (Adjusting & 4.293 & 0.011 & & & 2.443 & 0.003 \\
\hline
\end{tabular}




\begin{tabular}{|c|c|c|c|c|c|c|c|}
\hline \multirow[t]{6}{*}{ problems } & $\begin{array}{l}\text { for friendship- } \\
\text { quality) }\end{array}$ & & & & & & \\
\hline & $\begin{array}{l}\text { Group (Adjusting } \\
\text { for number of } \\
\text { friends) }\end{array}$ & 3.572 & 0.038 & & & 2.603 & 0.003 \\
\hline & $\begin{array}{l}\text { Group (Adjusting } \\
\text { for overall peer } \\
\text { victim) }\end{array}$ & 3.889 & 0.002 & & & 3.301 & 0.000 \\
\hline & $\begin{array}{l}\text { Group (Adjusting } \\
\text { for overall peer } \\
\text { bully) }\end{array}$ & 4.210 & 0.002 & & & 2.547 & 0.000 \\
\hline & $\begin{array}{l}\text { Group (Adjusting } \\
\text { for overall sibling } \\
\text { victim) }\end{array}$ & 4.588 & 0.001 & & & 2.777 & 0.000 \\
\hline & $\begin{array}{l}\text { Group (Adjusting } \\
\text { for overall sibling } \\
\text { bully) }\end{array}$ & 4.139 & 0.004 & & & 2.376 & 0.000 \\
\hline \multirow{7}{*}{$\begin{array}{l}\text { SDQ: Peer } \\
\text { Problems } \\
\text { Scale }\end{array}$} & Group only & 1.550 & 0.000 & -1.388 & 0.001 & & \\
\hline & $\begin{array}{l}\text { Group (Adjusting } \\
\text { for friendship- } \\
\text { quality) }\end{array}$ & 0.851 & 0.055 & -1.176 & 0.004 & & \\
\hline & $\begin{array}{l}\text { Group (Adjusting } \\
\text { for number of } \\
\text { friends) }\end{array}$ & 2.463 & 0.000 & -1.392 & 0.004 & & \\
\hline & $\begin{array}{l}\text { Group (Adjusting } \\
\text { for overall peer } \\
\text { victim) }\end{array}$ & 1.400 & 0.000 & -0.809 & 0.072 & & \\
\hline & $\begin{array}{l}\text { Group (Adjusting } \\
\text { for overall peer } \\
\text { bully) }\end{array}$ & 1.518 & 0.000 & -1.297 & 0.002 & & \\
\hline & $\begin{array}{l}\text { Group (Adjusting } \\
\text { for overall sibling } \\
\text { victim) }\end{array}$ & 1.792 & 0.000 & -1.134 & 0.009 & & \\
\hline & $\begin{array}{l}\text { Group (Adjusting } \\
\text { for overall sibling } \\
\text { bully) }\end{array}$ & 1.881 & 0.000 & -1.274 & 0.003 & & \\
\hline \multirow{5}{*}{$\begin{array}{l}\text { Functional } \\
\text { Impairment }\end{array}$} & Group only & 3.092 & 0.000 & -2.022 & 0.002 & 0.535 & 0.048 \\
\hline & $\begin{array}{l}\text { Group (Adjusting } \\
\text { for friendship- } \\
\text { quality) }\end{array}$ & 3.121 & 0.000 & -2.351 & 0.000 & 0.429 & 0.113 \\
\hline & $\begin{array}{l}\text { Group (Adjusting } \\
\text { for number of } \\
\text { friends) }\end{array}$ & 3.127 & 0.028 & -1.587 & 0.019 & 0.454 & 0.533 \\
\hline & $\begin{array}{l}\text { Group (Adjusting } \\
\text { for overall peer } \\
\text { victim) }\end{array}$ & 3.241 & 0.000 & -2.247 & 0.001 & 0.539 & 0.058 \\
\hline & $\begin{array}{l}\text { Group (Adjusting } \\
\text { for overall peer }\end{array}$ & 3.074 & 0.000 & -2.112 & 0.001 & 0.492 & 0.069 \\
\hline
\end{tabular}




\begin{tabular}{|l|l|l|l|l|l|l|}
\hline bully) & & & & & & \\
\hline $\begin{array}{l}\text { Group (Adjusting } \\
\text { for overall sibling } \\
\text { victim) }\end{array}$ & 2.806 & 0.000 & -1.913 & 0.004 & $\mathbf{0 . 4 7 5}$ & $\mathbf{0 . 1 5 0}$ \\
\hline $\begin{array}{l}\text { Group (Adjusting } \\
\text { for overall sibling } \\
\text { bully) }\end{array}$ & 2.841 & 0.000 & -1.928 & 0.004 & $\mathbf{0 . 4 5 7}$ & $\mathbf{0 . 1 6 3}$ \\
\hline
\end{tabular}

*Series of linear regressions: predictors: (1) group only; (2) group and friendship; (3) group and number of friends; (4) group and peer victim; (5) group and peer bully; (6) group and sibling victim; (7) group and sibling bully. Outcomes: School academic self-esteem; General self-esteem; physical health; peer problems; functional impairment.

Coefficients represent differences between groups before and after adjusting.

**Comparisons were made between:

Younger refugee children (1) compared to older refugee children (2).

Young control (1) compared to younger refugee children (2).

Young control (1) compared to older refugee children (2). 